\title{
SoTL as Sherwood Forest: A Review of the SoTL Commons Conference 2014
}

Every March, the historic town of Savannah, Georgia, turns into a gathering of thieves, eager to share and then redistribute the wealth amassed beneath the Spanish moss and azaleas. Armed with laptops, tablets, and notepads, we pilfer the treasures of pedagogical research brought by academic Robin Hoods from across the world and bring it back to the people we care about most: the students on our home campuses.

Before I started attending the annual SoTL Commons Conference five years ago, I drew from my own resources, often teaching in ways I'd planned during my drive home just the previous day. More often than not, I found the results wanting. When I learned about the Scholarship of Teaching and Learning (SoTL), I realized there was a rich collection of wisdom and practices from which I could supplement my individual stores. Eventually, I began contributing to the loot as well, expanding the shares available for fellow thieves and their students, and making a greater impact on student learning.

This year's conference again emphasized this broader goal of redistribution and impact. As the call for proposals reminded us, presentations about "a teaching practice or idea, but without any research regarding its effects upon student learning, are not appropriate for this conference." Rather than locking it away in a vault or using it only for own comforts, what we share and steal in SoTL is ultimately meant to be given back to students. The keynote addresses, three parts of an extended conversation, highlighted this very issue. Peter Felten laid the foundation by offering his "Principles of Good Practice in SoTL" (first offered at the 2011 ISSOTL conference in Milwaukee and then published in the first issue of Teaching \& Learning Inquiry) and asking, "to what end?" This question became one of the threads running through the conference hallway conversations, Q \& As, and other keynotes. Nancy Chick drilled down into Felten's third principle ("methodologically sound") by challenging participants to expand both the types of questions they ask and the ways they develop answers about student learning. Finally, Tony Ciccone looked to Felten's first principle, "inquiry focused on student learning," and asked us to consider the focus of these inquiries: beyond simple classroom "fixes," we should reflect on the big questions about student learning, such as those related to threshold concepts. The concurrent presentations were also little gems resulting from such SoTL inquiry.

Most memorable for me was a presentation about medical students using concept maps to enhance their "conceptual understanding" in ways that "moved the student towards more active learning, problem solving and reasoning” (Passmore, 2014, p. 28). During this session, I pocketed ideas and practices for my own work with calculus students. And so we thieves share, trade, and steal across disciplines, across states and nations, across 
institutional types - more gently described by Huber and Morreale as a "trading zone" (2002, p. 21), but I prefer the metaphor of Robin Hood because, while it's true that we come for "advice, collaborations, references, methods, and colleagues to fill in whatever [our] own disciplinary communities cannot or will not provide" (p. 19), the legendary thief of Sherwood Forest emphasizes the passion to enrich others with an educational bounty at any cost.

At the conference's close, we bring our full sacks back to our campuses. In the coming months, we'll share some of the wealth with our students in the form of best practices grounded in research. As SoTL scholars, we will revisit our recently acquired spoils and ask new-and important-questions. As colleagues, we will add good questions and research-based answers to our exchanges about teaching and learning. Ultimately, we all benefit from this annual larceny.

Kirthi Premadasa is an Associate Professor in Mathematics at University of Wisconsin-Baraboo/ Sauk County.

\section{REFERENCES}

Felten, P. (2013). Principles of good practice in SoTL. Teaching \& Learning Inquiry, 1(1). 121-125.

Huber, M. T. \& Morreale, S. P. (Eds.) (2002). Disciplinary styles in the scholarship of teaching and learning. Washington, D.C.: American Association for Higher Education.

Passmore, G. G. (2014, March). Concept mapping as a meaningful learning tool to promote conceptual understanding and clinical reasoning for resident and distance learning students. Paper presented at the SoTL Commons Conference 2014 Savannah, GA. 